Research Article

\title{
Exhaust Emission Characteristics of Heavy Duty Diesel Engine During Cold and Warm Start
}

\author{
YANG Rong ${ }^{*}$, LOU Di-ming and TAN Pi-qiang \\ School of Automobile Studies, Tongji University, Shanghai 201804, China
}

Received 1 March 2014; Accepted 18 July 2014

\begin{abstract}
Through experiment conducted on a six cylinder direct injection diesel engine with SCR catalyst, effects of coolant temperature on rail pressure, injection quantity, excess air coefficient and emissions characteristics during cold and warm start were investigated. The results showed that, the maximum injection quantity during a starting event was several times higher than idling operation mode, so was the maximal opacity in the cold and warm starting process. When coolant temperature rose up to above $20^{\circ} \mathrm{C}, \mathrm{NO}_{\mathrm{X}}$ emissions in the starting process exhibited peculiar rise which was times higher than idling mode. Compared with engine warm start, rail pressure, cycle fuel quantity, opacity, $\mathrm{CO}$ and $\mathrm{HC}$ emissions during engine cold start were higher in the course from their transient maximal values towards stabilized idling status. $\mathrm{NO}_{\mathrm{X}}$ in the same transient course, however, were lower in cold start. As coolant temperature rose, the maximal and the idling value of rail pressure and cycle fuel injection quantity during diesel engine starting process decreased gradually, the excess air coefficient increased to a certain degree, and the maximal and idling values of $\mathrm{NO}_{\mathrm{X}}$ increased gradually.
\end{abstract}

Keywords: heavy duty, diesel engine, cold start, warm start, emission

\section{Introduction}

At present, burning fossil fuels emits a large amount of greenhouse gas, $\mathrm{NO}_{\mathrm{X}}, \mathrm{PM}_{10}$ and $\mathrm{VOC}$ emissions, leading to severe environmental issues. Automotive technologies relating to energy saving and emissions reduction are increasingly focused on [1], [2]. In this regard, engine start/stop system and the associated starting process control are one of the key technologies in elaborating more economical and environmental operation in city "stop and go" pattern [3]. In addition, to improve fuel consumption and emissions, long time idling can be cancelled [4], [5]. But it can also lead to frequent engine start and stop operation [6], [7]. Frequent start and stop will directly affect coolant and oil temperature in engine starting up. Current diesel engine electronic control technology is based on such control strategy that during engine transient operation, the fuel injection quantity are compensated partially according to coolant and engine temperature, that is, the injection policy[8], [9], [10], [11], excess air coefficient and emissions characteristics differ a lot [12].

With the increasingly stricter emission legislations, exhaust emissions from diesel engine during cold and warm start are gradually being taken seriously. Euro VI emission legislations for heavy duty truck and bus engine test cycles WHSC (World Harmonized Stationary Cycle) and WHTC (World Harmonized Transient Cycle) have specifically required to examine emission characteristics of the engine starting [13]. Therefore, scholars have explored the emission characteristics of a diesel engine in cold, warm and hot start conditions. Henein et al. [7] investigated emissions of a

\footnotetext{
*E-mail address: yangrong0907@163.com

ISSN: 1791-2377 @ 2014 Kavala Institute of Technology. All rights reserved.
}

single cylinder direct injection and air cooled diesel engine under the cold and hot starts, and found that hot start transients produced $\mathrm{NO}_{\mathrm{X}}$ and $\mathrm{HC}$ emissions. Their work revealed that longer shut down periods produced less $\mathrm{NO}_{\mathrm{X}}$, but more $\mathrm{HC}$ emissions. Bielaczyc et al. [14] tested a $2 \mathrm{~L}$ diesel engine with turbo and oxidation catalytic converter during cold $\left(20^{\circ} \mathrm{C}\right.$ oil temperature) and warm $\left(90^{\circ} \mathrm{C}\right.$ oil temperature) starts, and found that the first 60 seconds of engine cold start operation were the most important because $53 \%$ of particulate matter and $41 \%$ of $\mathrm{CO}$ and $\mathrm{HC}$ were emitted during then. Besides, the amounts of compounds emitted in exhaust gases during cold start yielded greater production than obtained from the warm start. The amount of emitted HC and PM was several times higher for cold start, while in the case of CO this difference was of almost two magnitudes. These differences were more obvious during the first 30 seconds of engine starting course. Su et al. [15] researched on emission course of direct injection diesel engine with a mechanical speed governor during cold (start at $15^{\circ} \mathrm{C}$ temperature of coolant and oil condition) and warm start (start at $80^{\circ} \mathrm{C}$ temperature of coolant and oil condition). They found that the total exhaust emissions during cold start were higher than that during warm start, because of the fuel delivery was higher during cold start process. Dai et al. [16] studied the characteristics of cold and warm starting of a common rail DI engine which was equipped with EGR intercooled system. Cold start was tested at approximately $20^{\circ} \mathrm{C}$ room temperature, and warm start was tested at $90^{\circ} \mathrm{C}$ coolant temperature. They found that the NO emissions increased along with coolant temperature. THC, nucleation particle and accumulation particle emissions were reduced during warm start in most occasions because of the improved air/fuel premixing. Thus, emission characteristics are obviously different during cold and warm start. 
However, there is rarely documented literature about the performance and emission characteristics of a heavy duty diesel engine with SCR during cold and warm (with varying coolant temperatures) start conditions.

In this work, a heavy duty diesel engine with SCR catalyst for commercial vehicles was tested under cold start and warm start in different coolant temperatures. Further, it presented detailed cold and warm start behavior from rail pressure, injection quantity, excess air coefficient and emission characteristics.

\section{Experimental Equipment and Procedure}

\subsection{Test Engine}

Tests were conducted on a 7 liter six cylinder common rail DI diesel engine with SCR catalyst which was used for a commercial vehicle, and was fueled with Shanghai IV $0^{\#}$ diesel. Engine specifications were given in Table 1.

Tab. 1. The experimental engine specifications

\begin{tabular}{l|l} 
Tab. 1. The experimental engine specifications \\
\hline Component & Specification \\
\hline Displacement/L & 7.14
\end{tabular}

\begin{tabular}{l|l} 
Bore $\times$ Stroke $/(\mathrm{mm} \times \mathrm{mm})$ & $108 \times 130$ \\
\hline Compression ratio & $18: 1$ \\
\hline Idle speed $/\left(\mathrm{r} \cdot \mathrm{min}^{-1}\right)$ & 600 \\
\hline Turbocharger type & Holset HX40W turbocharger with wastegate \\
\hline After-treatment system & $\mathrm{SCR}$ \\
\hline
\end{tabular}

\subsection{Test Facilities}

An AVL PUMA open test bed system with highly dynamic capacity was used for the engine test. The AVL ConsysCool 553 coolant conditioning system was used for diesel engine coolant temperature control. AVL 439 opacimeter was used to measure transient exhaust opacity levels (visible smoke levels). And AVL AMAi60 exhaust measurement system was used for measurement of nitrogen oxides $\left(\mathrm{NO}_{\mathrm{X}}\right)$, carbon monoxide (CO) and hydrocarbons (HC). In addition, ETASINCA calibration kit was used to record rail pressure, cycle intake air mass and injection quantity. Figure 1 showed the schematic of the engine test bench.

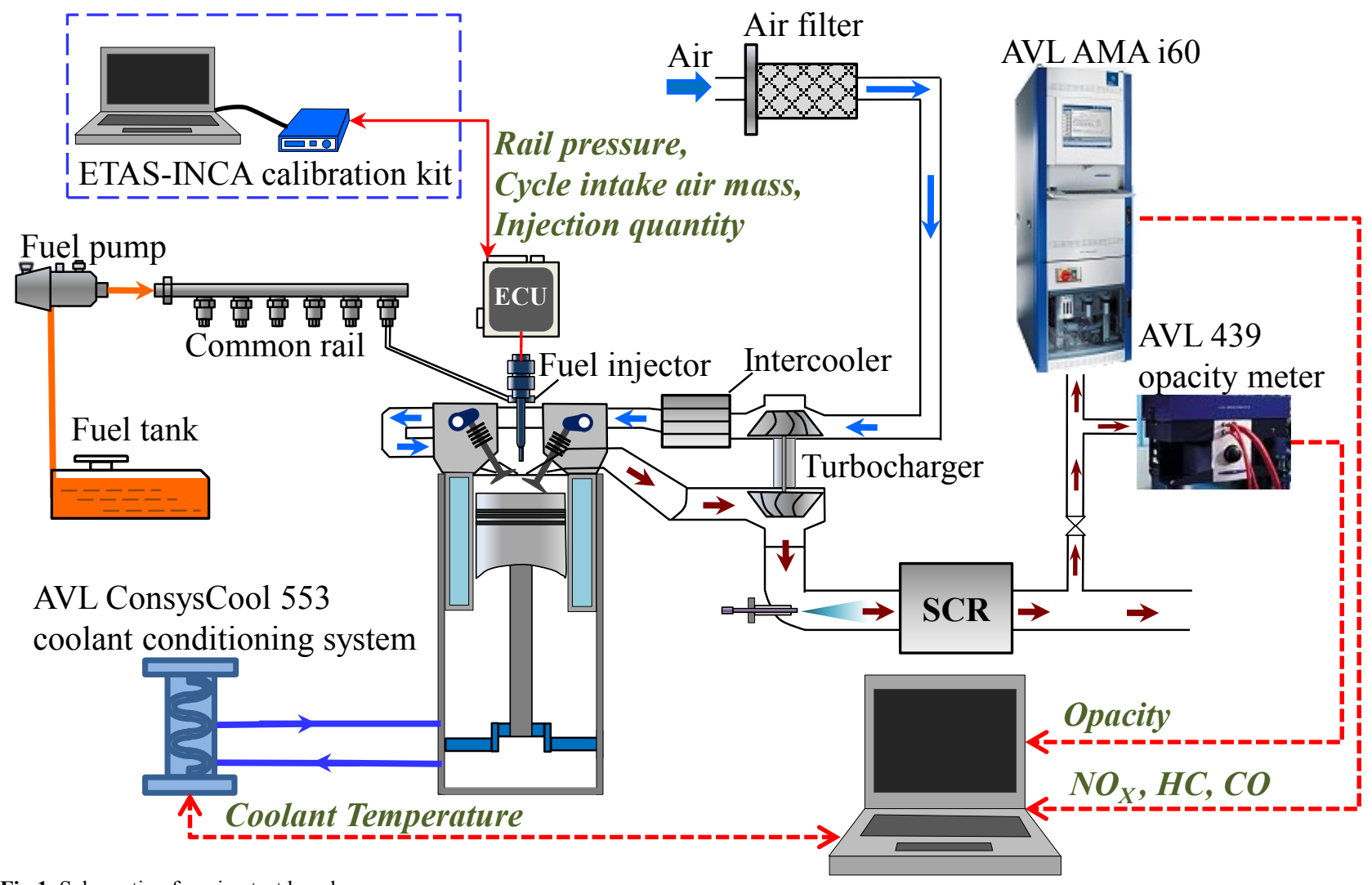

Fig.1. Schematic of engine test bench

\subsection{Experiment Procedure}

(1) Cold Start

The engine was soaked in laboratory with cooling air conditioning about $20^{\circ} \mathrm{C}$ temperature for at least 12 hours before start. Started the engine and kept it at idling condition for 60 seconds. Recorded the rail pressure, cycle air intake quantity, cycle fuel injection quantity and emissions from engine starting up to idling operation.

(2) Warm Start
Before the engine was started, it operated long enough to ensure coolant temperature reached about $87^{\circ} \mathrm{C}$ and oil temperature reached about $95^{\circ} \mathrm{C}$. The diesel engine and coolant conditioning system were afterwards shut down. And the engine was all at once cranked again until the coolant temperature rose up to the target temperature $60^{\circ} \mathrm{C}$ to $80^{\circ} \mathrm{C}$. Experimented data of the instant warm start procedure was recorded by the data acquisition system.

Warm start in $60^{\circ} \mathrm{C}$ coolant temperature hereinafter was referred to as $60^{\circ} \mathrm{C}$ warm start, so was defining method for $80^{\circ} \mathrm{C}$ warm start. 


\section{Results and Discussions}

\subsection{Rail Pressure}

Figure 2 showed the rail pressure evolution course during starting process. As shown in Figure 2, rail pressure kept $35 \mathrm{MPa}$ before the diesel engine started. After the engine started up, it reduced $8 \mathrm{MPa}$ at $1 \mathrm{~s}$, and then recovered quickly to $35 \mathrm{MPa}$ in $0.2 \mathrm{~s}$. Thereafter it rose quickly with fluctuations at about $1.33 \mathrm{~s}$, and reached the maximum value that about $41 \mathrm{MPa}$ to $45 \mathrm{MPa}$ at $1.53 \mathrm{~s}$, and then it dropped quickly to $36 \mathrm{MPa}$ to $39 \mathrm{MPa}$ during $1.7 \mathrm{~s}$ to $2.1 \mathrm{~s}$. After that, it rose rapidly first, and then the growth rate began to slow down at 2.6s. At last, it reached a steady state until about $5 \mathrm{~s}$. The maximum value of rail pressure during starting process was $2 \%$ to $6 \%$ higher than idling condition.

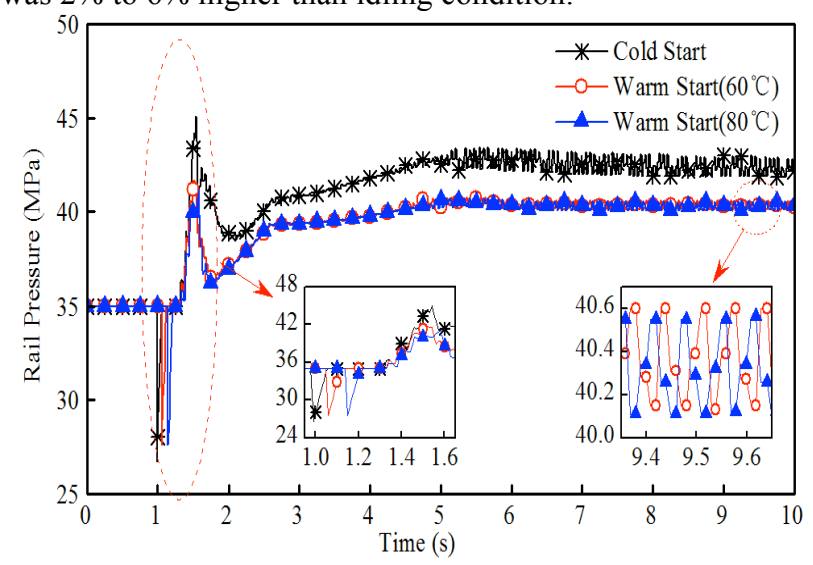

Fig.2. Rail pressure evolution course during starting process

During the process from the maximum value to idling value, the rail pressure was higher during cold start than warm start. During cold start, the rail pressure could reach a peak of $45 \mathrm{MPa}$, and was about $42.4 \mathrm{MPa}$ during the afterward idling. But there was scarce difference between 60 ${ }^{\circ} \mathrm{C}$ and $80{ }^{\circ} \mathrm{C}$ warm start, with $41.7 \mathrm{MPa}$ and $41.2 \mathrm{MPa}$ respectively for the maximum values and $40.4 \mathrm{MPa}$ for idling operation. Higher rail pressure during cold start was mainly to promote the fuel atomization and mixture formation, fostering fuel vaporization and penetration in relatively colder chamber environment.

As the coolant temperature rose, the time for rail pressure reduction was postponed, and the maximal and the idling value of rail pressure decreased.

\subsection{Fuel Injection Quantity}

Figure 3 showed cycle injection quantity evolution course during starting process. As shown in Figure 3, the injection quantity began to change at $1.1 \mathrm{~s}$. For all the three starting conditions, injection quantity of the first injection cycle was the maximum in the entire injection course, more than $60 \mathrm{mg} / \mathrm{hub}$, and 3.8 to 7 times higher than idling condition. Within $0.4 \mathrm{~s}$ after the first injection, cycle injection quantity experienced a slope shaped decrease mainly to reduce emissions and avoid misfiring [17]. Injection quantity reached the minimum value at about $2.2 \mathrm{~s}$, and then rose to a steady state gradually. This ensured to maintain a steady idling speed with less overshoot. After the moment fuel injection quantity reached a steady state at about $5 \mathrm{~s}$, there was a slight fluctuation due to PID functioning.

During the process from the maximum value to idling value, the cycle fuel injection quantity was higher during cold start than warm start. The cycle injection quantity could reach a peak of $75.9 \mathrm{mg} /$ hub during cold start, and was about
$15.6 \mathrm{mg} / \mathrm{hub}$ during idling. In the case of two warm starts, its injection counterpart was higher when the coolant temperature was $60^{\circ} \mathrm{C}$ before $1.5 \mathrm{~s}$, but there was little difference between $60^{\circ} \mathrm{C}$ and $80^{\circ} \mathrm{C}$ warm starts after $1.5 \mathrm{~s}$. The maximum value of fuel injection quantities for $60^{\circ} \mathrm{C}$ and $80^{\circ} \mathrm{C}$ warm starts were $16 \%$ and $21 \%$ lower than cold start respectively. For idling condition, the cycle fuel injection quantities for $60^{\circ} \mathrm{C}$ and $80^{\circ} \mathrm{C}$ warm start were about $50 \%$ lower than cold start. In addition, the minimum cycle fuel injection quantity during $60^{\circ} \mathrm{C}$ warm start was the lowest, followed by $80^{\circ} \mathrm{C}$ warm start and normal cold start.

Throughout the starting process, the maximum value and the idling value of cycle injection quantity decreased as the coolant temperature rose.

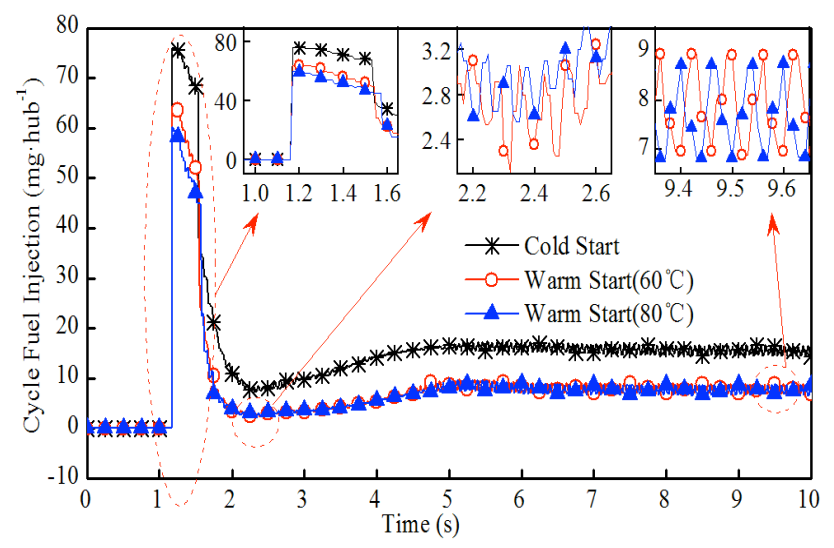

Fig.3. Cycle fuel injection evolution course during starting process

\subsection{Excess Air Coefficient}

Figure 4 showed the excess air coefficient evolution course during starting process. From Figure 2 and Figure 3, it could be seen that excess air coefficient during starting had contradictory behaviour to cycle fuel injection quantity. Excess air coefficient slightly rose during the $1.1 \mathrm{~s}$ to $1.53 \mathrm{~s}$, and then rapidly rose to the maximum value during the $2.2 \mathrm{~s}$ to 2.6s. The maximum value of excess air coefficient and the minimum value of cycle fuel injection quantity appeared almost at the same time. Excess air coefficient began to decrease after $2.6 \mathrm{~s}$, and achieved a steady state at about $5 \mathrm{~s}$, after then fluctuated slightly. During $1.1 \mathrm{~s}$ to $1.53 \mathrm{~s}$, excess air coefficient of starting conditions was about 1 to 1.9 , and about $80 \%$ lower than idling condition. During $2.2 \mathrm{~s}$ to $2.6 \mathrm{~s}$, the maximum value of excess air coefficient was about 13 to 42.8 , and about twice of that under idling condition.

During the process from the maximum value to idling value, excess air coefficient was lower during cold start than warm start. During cold start, excess air coefficient could reach a peak of 12.8, and was about 6 under idling condition. Excess air coefficient during $60^{\circ} \mathrm{C}$ warm start was closed to the $80^{\circ} \mathrm{C}$ warm start. The maximum value of excess air coefficient for $60^{\circ} \mathrm{C}$ and $80^{\circ} \mathrm{C}$ warm start were twice of cold start. Under idling condition, the excess air coefficient for $60^{\circ} \mathrm{C}$ and $80^{\circ} \mathrm{C}$ warm start were about $90 \%$ higher than the cold start. The maximum value of excess air coefficient during three starting were different, the order from the highest to the lowest was contrary to the minimum value of fuel injection quantity.

Throughout the starting process, excess air coefficient increased as the coolant temperature rose to a certain degree. In this study, it was from $1.1 \mathrm{~s}$ to $1.53 \mathrm{~s}$ periods when huge 
amount of injection was delivered and after $5 \mathrm{~s}$ when the engine was under idling condition.

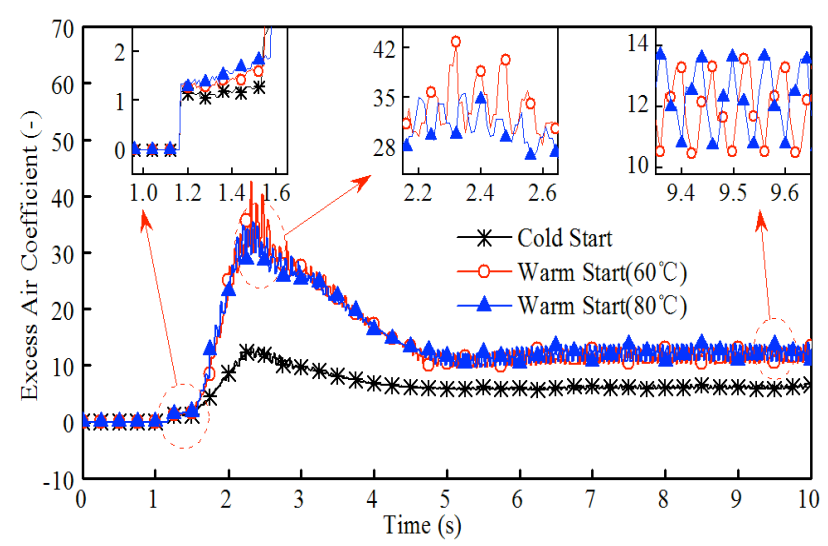

Fig.4. Excess air coefficient evolution course during starting process

\subsection{Exhaust Emissions Characteristics \\ 3.4.1 Opacity}

Figure 5 showed opacity variation with time during starting process. Compared with initial fuel injection time, initial opacity changing time lagged more than $2 \mathrm{~s}$ because there was a long pipeline from exhaust valves to opacimeter. As shown in Figure 5, opacity increased suddenly at the beginning, and kept a lower state after arriving idling condition. The maximum value of opacity during three starting processes were higher than 0.04 , and the order from the highest to the lowest was cold start, $80^{\circ} \mathrm{C}$ warm start and $60^{\circ} \mathrm{C}$ warm start, corresponding to maximum value 0.059 , 0.051 and 0.042 respectively. When engine operated under idling condition, the opacity was about 0.007 . In addition, the maximum value of opacity for $80^{\circ} \mathrm{C}$ warm start and $60^{\circ} \mathrm{C}$ warm start were $14 \%$ and $29 \%$ lower than cold start respectively. For both cold start and warm start, the maximum value of opacity was several times higher than idling condition during starting process.

Nonetheless, the maximum value of opacity in cold start was higher than warm start. It may be due to overrich, low excess air coefficient and partially evaporated fuel during cold start condition. During warm start conditions, the maximum value of opacity during $80^{\circ} \mathrm{C}$ warm start was higher than $60^{\circ} \mathrm{C}$ warm start. And compared to $60^{\circ} \mathrm{C}$ warm start, temperature in the cylinder was higher and rail pressure was lower during $80^{\circ} \mathrm{C}$ warm start when huge amount of fuel was delivered within $0.4 \mathrm{~s}$ after injection starts (see Figure 2). Due to lower rail pressure, fuel atomization fraction decreases, the chance of oxygen deficiency in high temperature cylinder increases, which was mainly responsible for higher peak opacity during $80^{\circ} \mathrm{C}$ warm start.

Initial change and the maximum value of opacity appeared earlier as the coolant temperature rose. This is mainly due to that, high coolant temperature might reduce the heat transfer to the cylinder wall and cause exhaust gas temperature rise, and then gas thermal movement speeds up, and emissions detection advances.

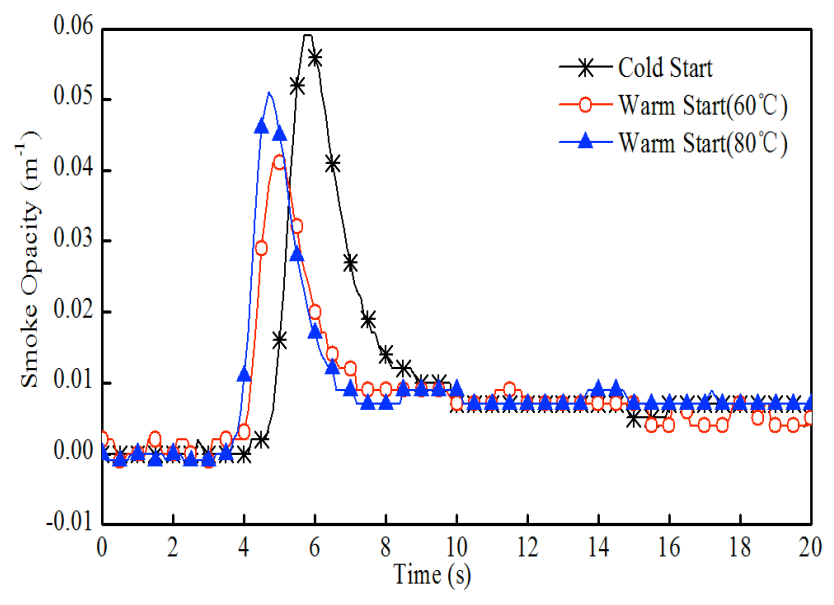

Fig.5. Opacity evolution course during starting process

\subsection{2 $\mathrm{NO}_{\mathrm{X}}$ emissions}

Figure 6 showed $\mathrm{NO}_{\mathrm{X}}$ evolution course during starting process. Temperature is one of the main limitations of the SCR catalyst. During engine starting process, exhaust temperature is too cool to prepare the catalyst to work. So the effect of SCR on $\mathrm{NO}_{\mathrm{X}}$ emissions could be eliminated. As shown in Figure 6, during starting, $\mathrm{NO}_{\mathrm{X}}$ increased rapidly first, and then decreased rapidly, thereafter increased to a steady state. During cold start, $\mathrm{NO}_{\mathrm{X}}$ concentration could reach a peak of $255 \times 10^{-6}$, and was higher than idling condition at a level about $63 \%$. During $60^{\circ} \mathrm{C}$ warm start it could reach a peak of $294 \times 10^{-6}$, was about $63 \%$ higher than idling condition. During $80^{\circ} \mathrm{C}$ warm start could reach a peak of $422 \times 10^{-6}$, and was higher than idling condition by $79 \%$. As stated above, it could be shown that, when coolant temperature reached higher than $20^{\circ} \mathrm{C}, \mathrm{NO}_{\mathrm{X}}$ emissions of electronic control system during starting process had a peculiar peak which was much higher than idling condition. In addition, the maximum and the idling value of $\mathrm{NO}_{\mathrm{X}}$ during cold start were the lowest. Compared to cold start, the maximum value of $\mathrm{NO}_{\mathrm{X}}$ for $60^{\circ} \mathrm{C}$ and $80^{\circ} \mathrm{C}$ warm start were $15 \%$ and $65 \%$ higher than cold start respectively, and idling value were $15 \%$ and $51 \%$ higher.

With the coolant temperature rose, $\mathrm{NO}_{\mathrm{X}}$ initial change appeared earlier, the maximum and idling value of $\mathrm{NO}_{\mathrm{X}}$ increased gradually.

The main formation conditions of $\mathrm{NO}_{\mathrm{X}}$ in diesel engine are high temperatures, oxygen enrichment and enough reaction time. As the coolant temperature rose, temperature of the combustion chamber wall increased, which was helpful to flourish fuel evaporation and mixture formation. After injecting certain amount of fuel during the earlier time of starting, mixture was compression ignited, and then high temperature environment in the cylinder was formed. From Figure 4, it could be observed that during starting process, the time averaged excess air coefficient was above 1, which meant combustion during starting was under a rich oxygen environment. Slower engine starting caused combustion cycle experienced a longer time. Therefore, there was a peculiar peak of $\mathrm{NO}_{\mathrm{X}}$ during starting process. Due to decreasing of injection quantity, and cooling of the chamber wall after combustion, $\mathrm{NO}_{\mathrm{X}}$ emissions decreased when engine operated under idling condition. 


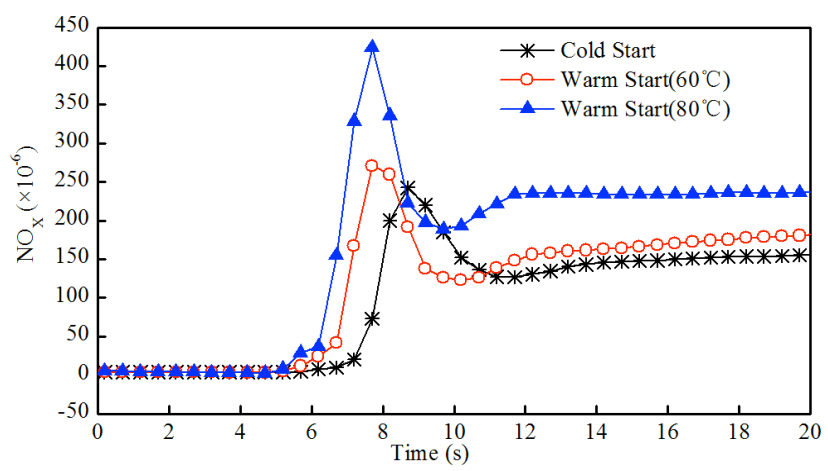

Fig.6. $\mathrm{NO}_{\mathrm{X}}$ evolution course during starting process

\subsubsection{CO emissions}

Figure 7 showed $\mathrm{CO}$ evolution course during starting process. As shown in Figure 7, CO increased first, and then decreased slightly to a steady state. Unlike smoke and $\mathrm{NO}_{\mathrm{X}}$, $\mathrm{CO}$ peak was not significant during starting, but $\mathrm{CO}$ emission during the cold start was significantly different from the warm start. $\mathrm{CO}$ concentration could reach $488 \times 10^{-6}$ during the cold start, times higher than warm start. Lack of heat from the cylinder walls was a challenge for the fuel to evaporate. Besides, higher fuel injection quantity during cold start made combustion with fuel-rich mixtures to produce high $\mathrm{CO}$ emissions.

Compared to $60^{\circ} \mathrm{C}$ warm start, the maximum value of $\mathrm{CO}$ was higher during $80^{\circ} \mathrm{C}$ warm start. It may because rail pressure was lower when large amount of fuel was injected at the beginning of $80^{\circ} \mathrm{C}$ warm start. And lower rail pressure caused deterioration of spray atomization quality and lead to poor combustion.

In addition, as the coolant temperature rose, initial $\mathrm{CO}$ change appeared earlier as opacity and $\mathrm{NO}_{\mathrm{X}}$, but $\mathrm{CO}$ under idling condition decreased gradually.

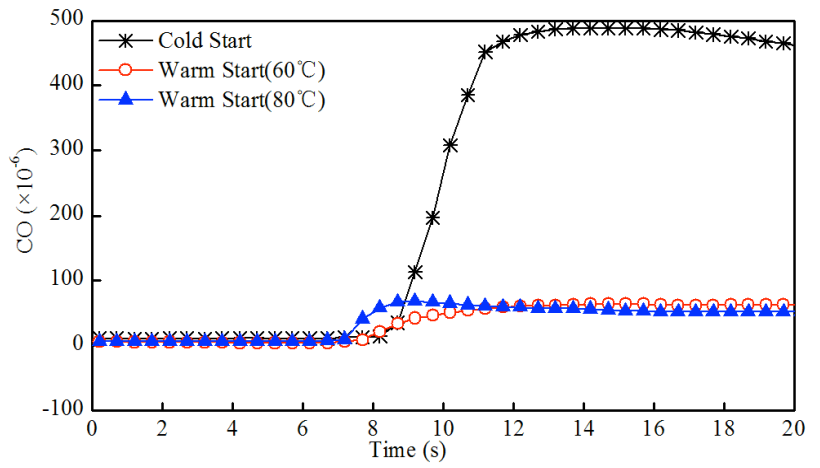

Fig.7. CO evolution course during starting process

\subsubsection{HC emissions}

Figure 8 showed $\mathrm{HC}$ evolution course during the starting process. As shown in Figure 8, HC of diesel engine with SCR catalyst was extremely low during the start process, which increased first, then decreased to a steady state. Similar to $\mathrm{CO}$, there was a significantly difference for $\mathrm{HC}$ between cold start and warm start. $\mathrm{HC}$ emissions concentration could reach $25 \times 10^{-6}$ during cold start, but only $5 \times 10^{-6}$ during $60^{\circ} \mathrm{C}$ and $80^{\circ} \mathrm{C}$ warm start.
Diesel engines may give rise to $\mathrm{HC}$ emissions where inadequately prepared mixture and temperature no longer sufficient for combustion. Local rich mixture zones could be other sources of HC emissions. During cold start, complete evaporation cannot be ensured, causing $\mathrm{HC}$ emissions to increase. However, $\mathrm{HC}$ emissions during $80^{\circ} \mathrm{C}$ warm start were a slightly lower than $60^{\circ} \mathrm{C}$ warm start, it was mainly due to less fuel injection [18].

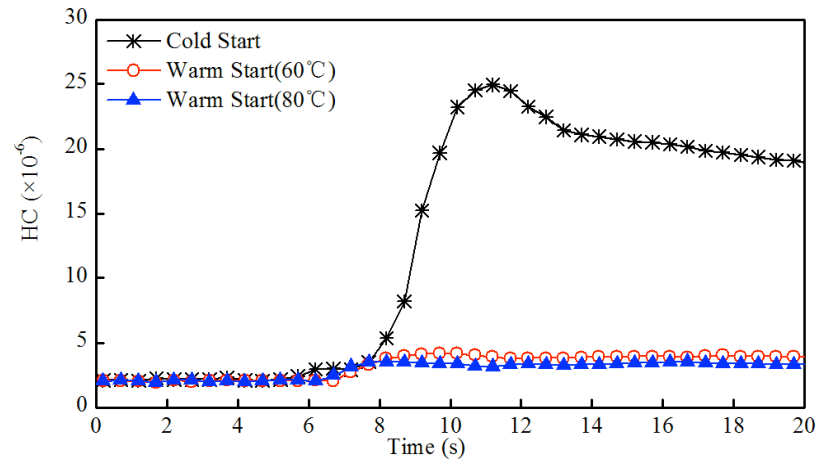

Fig.8. HC evolution course during starting process

\section{Conclusions}

When the electronic controlled diesel engine with SCR catalyst operated under cold and warm start conditions, the rail pressure, cycle injection quantity, excess air coefficient and emission characteristics were obviously investigated in this work.

(1) The maximum value of rail pressure during diesel engine starting process was greater than that under idling condition. And the maximum value of cycle injection quantity was 3.8 to 7 times higher. Both cold start and warm start, the maximum value of opacity was several times higher than that under idling condition during starting process. In addition, when coolant temperature was higher than $20^{\circ} \mathrm{C}$, there was an obvious peak of $\mathrm{NO}_{\mathrm{X}}$ which was much higher than idle state during starting process.

(2) During the process from the maximum value to idling value, rail pressure and cycle injection quantity during cold start were higher than that during warm start, and with no significant difference between $60^{\circ} \mathrm{C}$ and $80^{\circ} \mathrm{C}$ warm start. Opacity, $\mathrm{CO}$ and $\mathrm{HC}$ emissions during cold start were higher than warm start, especially for $\mathrm{CO}$ and $\mathrm{HC}$ emissions, but the maximum value and idling value of $\mathrm{NO}_{\mathrm{X}}$ emissions were lower.

(3) As coolant temperature rose, the maximum and idling value of rail pressure and cycle injection quantity during diesel engine starting process decreased gradually; excess air coefficient increased to certain degree; initial change time of smoke, $\mathrm{NO}_{\mathrm{X}}$ and $\mathrm{CO}$ rose; and the maximum and idling value of $\mathrm{NO}_{\mathrm{X}}$ emissions increased gradually.

\section{Acknowledgements}

This project was supported by Key Projects in the National Science \& Technology Pillar Program during the Twelfth Five-year Plan Period [2011BAG04B01]. 


\section{References}

1. EEA, "Transport emissions of air pollutants (TERM 003) Assessment published Feb 2013", http://www.eea.europa.eu/dataand-maps/indicators/transport-emissions-of-air-pollutants-8/transp ort-emissions-of-air-pollutants-9.

2. Ministry of Environmental Protection of the People's Republic of China, "Annual report of 2013 motor vehicle pollution control in China", 2013.

3. FEV Inc, "In-market Application of Start-Stop Systems in European Market", http://www.theicct.org/sites/default/files/FEV LDV\%20EU\%20Technology\%20Cost\%20Analysis_StartStop\%20O verview.pdf.

4. Aoyagi, S., Hasegawa, Y., Yonekura, T., et al., "Energy efficiency improvement of series hybrid vehicles", JSAE Review 3(22), 2001, pp. 259-264.

5. Tanaka, K., Korematsu, K., Yamazaki, Y., "Study on Intelligent Idling Stop System", Seoul 2000 FISITA World Automotive Congress, F2000I392, Seoul, Korea, 12-15 June, 2000.

6. Ambühl, D., "Energy management strategies for hybrid electric vehicles", Ph. D. Thesis, Switzerland: ETH Zurich, 2009.

7. Henein, N., Taraza, D., Chalhoub, N., Lai, M., et al., "Exploration of the Contribution of the Start/Stop Transients in HEV Operation and Emissions", SAE Technical Papers 2000-01-3086, 2000.

8. Rober Bosch GmbH, "Diesle-engine Management ( $3^{\text {rd }}$ edition)", US SAE International, 2004.

9. Wang, H. Q., Li, J., "Fuel Injection System Control Mode of Diesel Engine during Cold Start", Automobile Technology, (06), 1999, pp. $15-18$

10. Wang, H. R., Zhang, H., Wang, Y. F., "The research of starting control strategies for common rail diesel engine", Lecture Notes in Electrical Engineering- FISITA 2012 World Automotive Congress, Beijing, China, 27-30 November, 2012. Heidelberg: Springer Verlag, 2013, pp. 53-62.
11. Zhang, B., Li, L. R., Dong, W., "Influence of Temperature on Starting Performance of Common Rail Diesel Engine", Automobile Technology, (07), 2009, pp. 31-33, 55.

12. Tan, P. Q., Zhao, J. Y., Hu, Z. Y., et al., "Exhaust Emissions of a Diesel Car During Cold Start in Real World”, Chinese Journal of Automotive Engineering, 1(03), 2011, pp. 192-197.

13. Ecopoint Inc, "Heavy-Duty Truck and Bus Engines (Emission Standards - European Union)", https://www.dieselnet.com/ standards/eu/hd.php.

14. Bielaczyc, P., Merkisz, J., Pielecha, J., "Investigation of Exhaust Emissions from DI Diesel Engine during Cold and Warm Start", SAE Technical Papers 2001-01-1260, 2001.

15. Su, Y., Liu, Z. C., Xu, Y., et al., "Exhaust emission histories of direct injection diesel engine during start", Journal of Jilin University (Engineering and Technology Edition), 37(04), 2007, pp 762-766.

16. Liu, D., Xu, H., Tian, J., Tan, C., et al. "Cold and Warm Start Characteristics using HVO and RME Blends in a V6 Diesel Engine", SAE International Journal of Fuels and Lubricants, 6(2), 2013, pp.478-485.

17. Lei, T., Dong, S., "Study of Injection Strategy for Diesel Start", Modern Vehicle Power, (03), 2010, pp. 39-41, 60.

18. Dong, W., Yu, X. M., Yu, H. Y., et al., "Influences of starting fuel quantity and main injection advance angle on starting characteristics of common rail diesel engine", Nongye Gongcheng Xuebao/Transactions of the Chinese Society of Agricultural Engineering, 25(03), 2009, pp. 64-68. 